\title{
O trabalho no século XXI e o novo adeus à classe trabalhadora
}

work in the 21st century and the new goodbye to the working class vitor Filgueiras* sávio cavalcante**

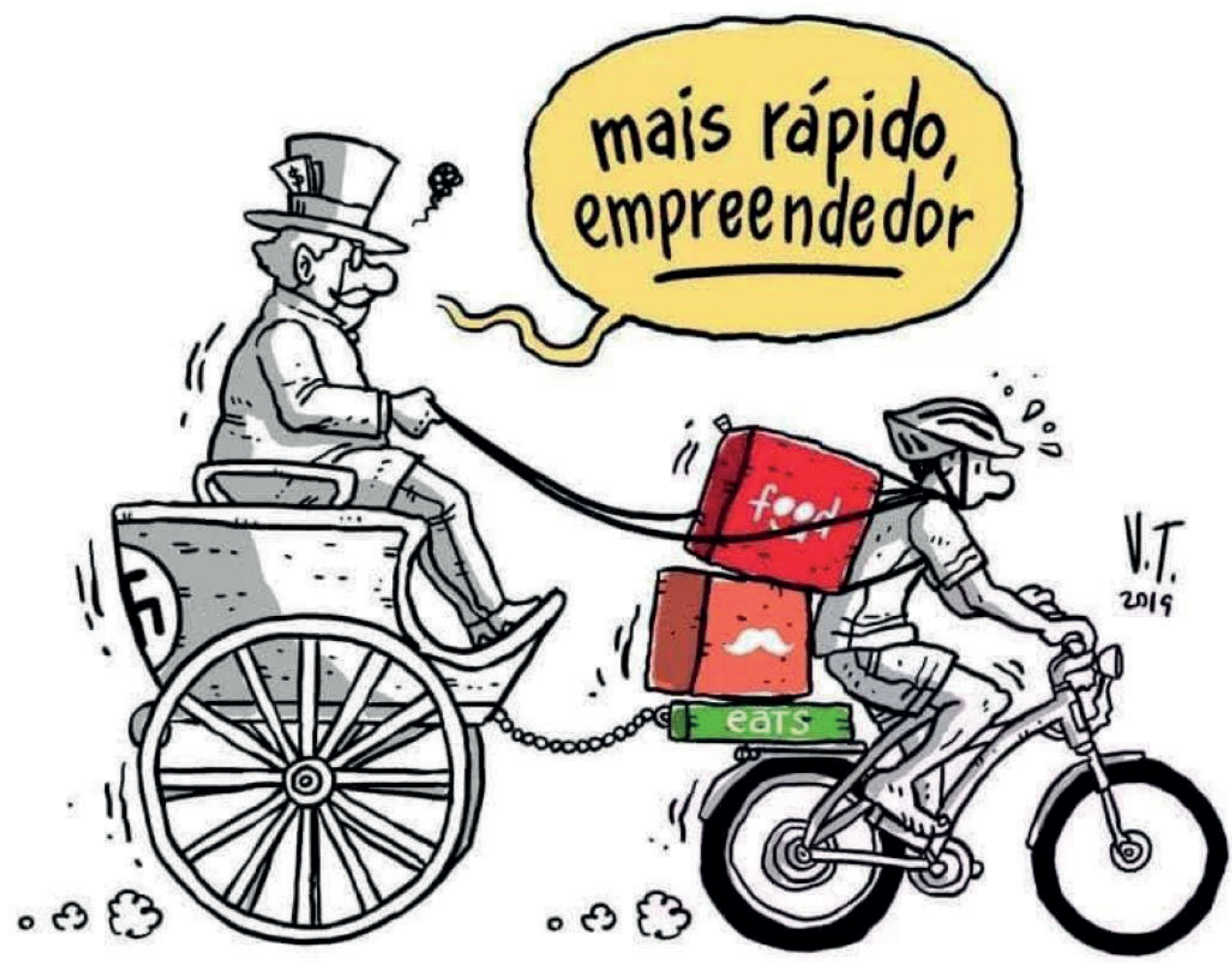




\section{RESUMO}

A ideia de que supostas novas formas de trabalho estariam substituindo o assalariamento como modo predominante de organização do trabalho tem engendrado uma espécie de novo adeus à classe trabalhadora. O objetivo central deste texto é analisar esse novo adeus, que tem sido promovido por diferentes agentes nas últimas décadas, atualmente ainda mais propalado com o uso das novas tecnologias da informação e comunicação (TICs). Contudo, as formas de organização da produção e do trabalho que têm sido apresentadas como novidades nas primeiras décadas do século XXI não diferem, em seu conteúdo, do trabalho assalariado. Empresas, instituições e academia têm reproduzido uma narrativa que chamamos de novo "adeus à classe trabalhadora" e que, deliberadamente ou não, contribui para a estratégia do capital em aumentar seu poder, tornando o trabalho mais precário e os trabalhadores menos propensos a enfrentar a exploração. Para desenvolver tais argumentos, faremos uma breve revisão da literatura e, em seguida, analisaremos alguns dos casos mais divulgados e destacados das chamadas "novas" formas de trabalho que estariam substituindo o assalariamento.

Palavras-chave: Gestão do trabalho; Assalariamento; Regulação.

\section{ABSTRACT}

The idea that so-called new forms of work would be replacing wage labour as the predominant way of organising work has created a new farewell to the working class. This paper aims to analyse this new farewell, which has been promoted by different agents over the last decades, currently even more popular with the use of new information and communication technologies (ICTs). However, the organisation of production and forms of work that have been shown as novelties in the first decades of the 2Ist century do not differ, in content, from wage labour. Companies, institutions and academia have reproduced a narrative that we call the new "farewell to the working class" that, deliberately or not, contributes to the strategy of the capital to increase its power, making work more precarious and the workers less likely to face exploration. In order to develop such arguments, we will briefly review the literature and then analyse some of the most broadcasted and prominent cases of the so-called "new" forms of work that would be replacing wage labour.

Keywords: Work management; Wage labour; Regulation 


\section{INTRODUÇ̃̃O}

Nas primeiras décadas do século XXI, têm sido crescentes as alusões e análises sobre grandes transformações na organização e natureza das relações de trabalho. Nos últimos anos, em especial, essas supostas mudanças estariam associadas à utilização de novas tecnologias, particularmente da informação e comunicação.

Não é a primeira vez que são anunciadas grandes mudanças no mundo do trabalho em escala global. É recorrente a tese de que determinadas transformações levariam até mesmo à perda de centralidade do trabalho em nossa sociedade. Esse chamado adeus ao trabalho, todavia, não se confirmou (ANTUNES, I995). E, mais recentemente, uma retórica semelhante vem divulgando a tese de que supostas novas formas de trabalho estariam substituindo o assalariamento como modo predominante de organização do trabalho, engendrando uma espécie de novo adeus à classe trabalhadora (FILGUEIRAS; CAVALCANTE, 2020).

O objetivo central deste texto é analisar esse novo adeus à classe trabalhadora, que tem sido promovido por diferentes agentes nas últimas décadas, atualmente ainda mais propalado com o uso das novas tecnologias da informação e comunicação (TICs). Como o primeiro, decretado na década de I980, o novo adeus apresenta inconsistências de diversas ordens: teórica, porque naturaliza de forma acrítica o determinismo tecnológico; empírica, pois superestima a forma dos contratos e negligencia o conteúdo objetivo das relações; e, por fim, política, porque dificulta a construção de uma luta social adequada à urgente proteção dos direitos trabalhistas.

Os principais argumentos aqui apresentados são:

1) as formas de organização da produção e do trabalho que têm sido apresentadas como novidades nas primeiras décadas do século XXI não diferem, em seu conteúdo, do trabalho assalariado. Pelo contrário, são estratégias de gestão que, adotando como uma de suas ferramentas a negação da condição de assalariamento (combinada ou não com o emprego das TICs), têm radicalizado o controle, a subordinação e a exploração dos trabalhadores;

2) empresas, instituições e academia têm reproduzido uma narrativa que chamamos de novo "adeus à classe trabalhadora" e que, deliberadamente ou não, contribui para a estratégia do capital em aumentar seu poder, tornando o trabalho mais precário e os trabalhadores menos propensos a enfrentar a exploração ${ }^{1}$. Isso ocorre porque a tese da disseminação de novas formas de trabalho favorece a legitimação de

1 Quando usamos a expressão estratégias do capital, fazemos referência a um processo histórico-social complexo que inclui a forma pela qual diferentes grupos de trabalhadores criam e recriam formas de resistência, conflito e adaptação. Aqui, focando-nos conforme indicado em como essas estratégias são formuladas, o objetivo é justamente identificar essas lógicas para compreender como afetam a luta dos trabalhadores. Também reconhecemos que o debate sobre classes sociais é mais amplo e os grupos assalariados possuem clivagens que levam, por exemplo, à discussão sobre a diferença entre a classe trabalhadora (entendida pelo conceito tradicional de proletariado) e a classe média (Cavalcante, 2012). No entanto, os argumentos aqui apresentados sobre a dinâmica dos mercados de trabalho estão localizados em um nível do problema que não requer tal discussão sobre as divisões internas dos assalariados. 
modelos precarizantes de contratação e gerenciamento de trabalho, apresentando-as como inexoráveis e incompatíveis com o direito do trabalho.

Para desenvolver tais argumentos, faremos uma breve revisão da literatura e, em seguida, analisaremos alguns dos casos mais divulgados e destacados das chamadas "novas" formas de trabalho que estariam substituindo o assalariamento. Iremos focar os casos do mercado de trabalho brasileiro, britânico e espanhol. Embora esses países possuam estruturas produtivas distintas e diferenças em seus mercados de trabalho e em suas formas de regulação social, foram escolhidos como uma maneira de analisar tendências gerais que afetam os países centrais e periféricos.

Ao longo das últimas duas décadas, temos realizado vários estudos de caso sobre algumas das mais famosas "novas" formas de trabalho para analisar seu conteúdo e verificar se e como elas diferem do emprego tradicional em termos de subordinação ao capital. São casos representativos de setores e empresas que alcançaram destaque em escala global, e também são indicados como tendências prováveis para o mercado de trabalho como um todo. Portanto, a análise busca articular uma dimensão maior do processo com a descrição de situações típicas nas quais o objeto dessa discussão pode ser avaliado em sua expressão concreta. Este texto é uma atualização da parte empírica do artigo "O que mudou: um novo adeus à classe trabalhadora?” (FILGUEIRAS; CAVALCANTE, 2020), publicado na Revista Brasileira de Ciências Sociais.

\section{DO PRIMEIRO AO NOVO ADEUS À CLASSE TRABALHADORA}

O primeiro adeus à classe trabalhadora é fruto de um conjunto de obras que, na década de I980, procuravam reposicionar conceitos, categorias e métodos de análise que se concentravam no emprego e nas relações de trabalho nas sociedades capitalistas $^{2}$ (2). Destacam-se as intervenções de Gorz (1982) e Offe (1989).

Os argumentos eram diversos, mas todos de alguma maneira convergiam na identificação de uma mudança principal: a automação promovida pela microeletrônica tendia a tornar marginal, ou mesmo abolir, o trabalho humano na produção material. Nos outros setores, comumente chamados de serviços, haveria ainda a necessidade de atividades humanas, mas o conteúdo de tais atividades exigiria outra racionalidade, um trabalho mais "reflexivo", irredutível à quantificação econômica em moldes tradicionais. Não haveria, no limite, o mesmo sentido de trabalho tradicional.

Para alguns autores, como Gorz, essas mudanças deveriam alterar as lutas progressistas. Se o trabalho perde sua condição de critério de integração social planos de pleno emprego seriam inviáveis nesse contexto - , a cidadania precisaria ser garantida por outras políticas, mais voltadas à distribuição de riqueza do que à produção. Daí surge a base de justificação das políticas de renda básica.

As repercussões desse debate no campo acadêmico das relações de trabalho foram extensas. Antunes (1995) elaborou uma crítica ao "adeus ao trabalho" que, entre

2 Para uma descrição mais detalhada, ver Filgueiras e Cavalcante (2020) e Antunes (1995). 
outros argumentos, destacou dois limites para essa posição teórica. O primeiro foi o caráter eurocêntrico dos diagnósticos realizados pelos autores, na medida em que a globalização do circuito produtivo capitalista recria milhões de empregos tipicamente industriais em outras regiões do mundo. Quanto ao segundo limite, Antunes argumentou que o setor industrial e o de serviços apresentam mais semelhanças do que diferenças entre si, mesmo na Europa. De fato, a ofensiva neoliberal à proteção das condições de venda da força de trabalho encoraja formas de emprego distintas do padrão fordista típico, mas isso não implica uma redução qualitativa e quantitativa na existência de grupos de assalariados cujas vidas foram subsumidas pela lógica capitalista.

Não pretendemos desconsiderar a magnitude dos fenômenos que foram objeto dessa discussão. Houve uma mudança acentuada na estrutura ocupacional em vários países centrais e uma parte crescente da força de trabalho foi incorporada em formas flexíveis de contratação. O quadro era ainda mais agudo no caso de países com capitalismo dependente que já tinham a informalidade e precariedade como a principal característica de seus mercados de trabalho.

Mas o ponto aparentemente mais decisivo é que esse adeus ao trabalho foi informado por um diagnóstico da situação que deu à mudança tecnológica um papel proeminente e inevitável. Assim, estabeleceu-se uma relação causal entre o que seria a perda de relevância do trabalho como fonte de riqueza - ou mesmo a suposta dificuldade de medir algumas atividades econômicas - e a dificuldade de reconstruir padrões estáveis de regulação do emprego. A determinação foi apresentada como mais técnica do que política e social. É precisamente esse ponto que constitui o elo entre o primeiro e o que descrevemos aqui como o novo adeus ao trabalho.

O que chamamos de novo adeus à classe trabalhadora retoma essa base argumentativa, mas apresenta uma característica nova: concede uma ênfase forte ao que seria um declínio estrutural do trabalho assalariado e à impossibilidade de reconstruir padrões de regulação do emprego por meio do direito do trabalho. Uma mudança notável nesse novo adeus é que, diferentemente do primeiro, a noção de fim do trabalho em geral, como afirma Gorz, é menos explícita. Trabalho sempre haverá, mas a noção de emprego não caberia mais para tipificar essas atividades. Enfatiza-se, nesse sentido, que não apenas o trabalho industrial, mas todo o trabalho assalariado estaria em declínio diante do surgimento de "novas" formas de organização. O que está em questão é a impossibilidade de recuperar ou construir padrões de regulação com base nas noções de empregador e empregado.

Esse novo adeus é construído por perspectivas diferentes, mas as suposições e conclusões são semelhantes: a) o trabalho assalariado está em declínio; b) as novas características do mercado de trabalho impedem a proteção do trabalho por meio de legislações já existentes.

Existem pelo menos três diferentes abordagens que unem esse campo. A mais radical afirma que o trabalho por conta própria está aumentando e que tende a substituir o assalariamento. A segunda abordagem afirma que estão crescendo novas 
formas de trabalho que não se enquadram no trabalho assalariado nem no trabalho por conta própria, constituindo o que é chamado de zona cinzenta ou terceira via. A terceira é apresentada por Guy Standing (20II; 20I4; 20I6), por meio do seu conceito de precariado, uma nova classe social que estaria crescendo enquanto os assalariados e o proletariado encolheriam em todo o mundo.

As duas primeiras abordagens são normalmente combinadas para enfatizar as mudanças nos mercados de trabalho. Elas aparecem, por exemplo, em uma publicação da Organização Internacional do Trabalho (OIT) de 20I5, sugestivamente chamada de "A mudança na natureza dos empregos" (traduções nossas):

Em várias economias avançadas, a incidência de emprego remunerado e assalariado tem apresentado uma tendência de queda, afastando-se, portanto, dos padrões históricos. Por outro lado, o trabalho por conta própria e outras formas de emprego fora do escopo do acordo tradicional empregador-empregado estão em ascensão (ILO, 20I5, p. I3).

Essas considerações normalmente são baseadas nos seguintes argumentos:

Novas tecnologias e mudanças na maneira como as empresas organizam a produção são fatores-chave por trás da mudança nas relações de emprego e da expansão de novas formas de trabalho. Atingir o modelo de emprego-padrão para a maioria dos trabalhadores está se tornando mais difícil (ILO, 20I5, p. I4).

A suposição de que "novas formas de trabalho" têm aumentado também é muito relevante em países de capitalismo dependente, como o Brasil, o que pode ser teoricamente baseado na crise do fordismo como padrão de organização do trabalho: O fim da norma fordista de trabalho - como norma, o que não impede a existência de trabalhos caracterizáveis como fordistas — obriga à reflexão sobre as várias formas e diferenciações que o trabalho e o emprego assumem. Essas diferenciações se encontram na origem do "embaralhamento" das fronteiras salariais e da constituição de uma "zona cinzenta" relativa às novas relações de trabalho e emprego. Essa "zona cinzenta" exige tanto a revisão quanto a criação de novos conceitos no âmbito da sociologia do trabalho. [...] Entre as formas emergentes de inserção pelo trabalho, destaca-se o autoempreendedorismo como objeto emblemático de uma relação de trabalho em substituição a uma relação de emprego, uma vez que se tornar empreendedor de si significa uma forma de distensão da relação de emprego (ROSENFIELD, 20I5, p. II5-II6).

Além do campo acadêmico, empresas e seus representantes pressionam a regulação pública usando essa nova hipótese. Por exemplo, de acordo com o Financial Times: À medida que a tecnologia e a globalização perturbam e fragmentam o mundo do trabalho, alguns advogados afirmam que os status legais de emprego 


\section{O precariado é inerentemente instável, seus membros estão sempre prontos para um trabalho incerto, não têm controle sobre seu tempo e dependem exclusivamente do salário para sobreviver (porque não têm direitos trabalhistas)}

são antiquados demais para capturar a complexidade de muitas relações de trabalho modernas (O'CONNOR, 20I5, tradução nossa).

A expansão de "novas" formas de trabalho e o anacronismo da regulação protetiva do trabalho têm sido fortemente reivindicados por instituições privadas, como a Confederação Nacional da Indústria (CNI) no Brasil:

A disseminação das tecnologias da informação criou um novo mundo para o trabalho. Existem atividades intensivas em conhecimento que podem ser desenvolvidas por um grupo de pessoas espalhadas pelo país ou pelo mundo. Sendo especializado, esse tipo de trabalhador pode atender às demandas de diferentes empresas. Você pode trabalhar em casa, sem perder tempo no trânsito, determinando seus horários da maneira que melhor lhe convier. No entanto, as modernas relações de trabalho do século XXI ainda são reguladas por normas obsoletas da primeira metade do século XX (CNI, 20IO, p. IO9).

As características desse novo mundo do trabalho, ainda que tomadas de maneira crítica, também informam a análise de Standing (20I4; 20I6). Segundo o autor, o mundo está passando por uma transformação global análoga à grande transformação identificada por Karl Polanyi (200o). Hoje, no entanto, o sistema de mercado é global, enquanto Polanyi analisara a criação de economias de mercado nacionais. $\mathrm{O}$ precariado emergiu dessa nova estrutura, sendo uma classe caracterizada por incerteza e insegurança crônicas. Standing afirma que o precariado apresenta diferentes relações de produção, distribuição e direitos em comparação com os assalariados e o proletariado. O precariado é inerentemente instável, seus membros estão sempre prontos para um trabalho incerto, não têm controle sobre seu tempo e dependem exclusivamente do salário para sobreviver (porque não têm direitos trabalhistas). Em resumo, Standing afirma que, enquanto na grande transformação o capital nacional admitiu um trabalho estável para o núcleo do proletariado, hoje o capital global impõe completa instabilidade ao precariado. $\mathrm{O}$ autor vê essa diferença como fundamental para diferenciar o precariado de outras classes. 
Para Standing, estamos experimentando uma revolução nas formas de trabalho que inviabiliza a regulação anterior para proteger os trabalhadores. $\mathrm{O}$ tipo de trabalho que cresce mais rapidamente é o que ele chama de trabalho em multidão, realizado pelos responsáveis pelas tarefas (taske$r s$ ), que fazem parte do precariado e realizam atividades sem direitos trabalhistas, estabilidade ou garantia de renda. Os taskers trabalham por meio do que seriam intermediários (labour brokers), a exemplo de novas empresas como a Uber. Para Standing, por não possuírem juridicamente os instrumentos de trabalho ou os meios de produção, essas empresas são rentistas. Segundo o autor, os taskers

Não são empregados, pois não são diretamente supervisionados, possuem os principais meios de produção e, em princípio, têm controle sobre o tempo de trabalho. [...] Eles também não são autônomos, pois dependem dos intermediários para acessar os aplicativos. Mas eles têm de suportar a maioria dos riscos, acidentes, problemas de saúde, reparos e manutenção. Eles fazem parte do núcleo do precariado (STANDING, 20I6, tradução nossa).

Standing afirma que as características do antigo sistema de regulação do trabalho são inadequadas para a realidade atual, defendendo uma renda básica universal como política pública para o precariado.

Nos últimos anos, esse novo adeus à classe trabalhadora se radicalizou com a disseminação dos chamados "aplicativos" e "plataformas", que não apenas negam a natureza assalariada da relação entre empresa e trabalhadores, mas rejeitam o próprio caráter laboral da relação, imputando aos trabalhadores a condição de clientes das empresas, como veremos à frente.

Portanto, o que estamos chamando de novo adeus à classe trabalhadora, visão que considera irreversível o declínio do emprego assalariado e que o direito do trabalho não é uma solução para o contexto atual, parece reunir muitas perspectivas ideológicas diferentes. Essa narrativa tem tido grande impacto entre trabalhadores e instituições de regulação. $\mathrm{O}$ presente texto busca analisar a consistência empírica desse novo adeus à classe trabalhadora. 


\section{O que estamos chamando de novo adeus} à classe trabalhadora, visão que considera irreversível o declínio do emprego assalariado e que o direito do trabalho não é uma solução para o contexto atual, parece reunir muitas perspectivas ideológicas diferentes. Essa narrativa tem tido grande impacto entre trabalhadores e instituições de regulação

\section{A NATUREZA DAS “NOVAS" FORMAS DE TRABALHO}

Esta seção aborda a seguinte pergunta: as "novas" formas de trabalho são realmente novas em termos de conteúdo, ou são relações assalariadas intencionalmente dissimuladas pelas empresas como estratégia de gestão?

Inicialmente, é importante enfatizar que parte das estatísticas de trabalho autônomo exibidas em pesquisas nacionais em todo o mundo, especialmente em países subdesenvolvidos, refere-se, de fato, a trabalhadores independentes que se envolvem em atividades por conta própria (normalmente de forma precária). Proprietários de pequenas empresas, como barbearias, vendedores de rua e de mercado, profissionais de manutenção doméstica (encanadores, eletricistas etc.) e pequenos agricultores, por exemplo, sempre existiram e provavelmente sempre existirão em qualquer sociedade capitalista. Assim, não há novidade nessas situações.

O tema aqui abordado são as "novas" formas de trabalho que supostamente surgiram nas recentes transformações das sociedades capitalistas. Escolhemos analisar alguns casos que consideramos representativos devido à sua repercussão, incidência ou aumento recente.

Antes da análise dos casos é também preciso ressaltar que, apesar de muitas alegações em contrário, de acordo com dados agregados que cobrem as últimas décadas, o trabalho assalariado cresceu em todo o mundo. Conforme demonstramos em outro trabalho (FILGUEIRAS; CAVALCANTE, 2020), mesmo nos países em que o trabalho por conta própria aumentou nos últimos anos, não há indicadores sustentáveis que mostrem um declínio estrutural do trabalho assalariado. A participação percentual das diferentes formas de inserção no mercado de trabalho depende fundamentalmente do desempenho do mercado de trabalho e do papel da regulação protetiva do Estado e da resistência dos trabalhadores. 


\section{I. Muitos nomes para uma mesma relação}

Nos últimos anos, o tema dos aplicativos, plataformas, gig economy, dentre outras denominações, tem sido muito enfatizado como a grande "novidade" dos mercados de trabalho em todo o mundo. Contudo, muito antes da existência das "plataformas" e dos "aplicativos", já se declarava a expansão de "novas" formas de trabalho. Portanto, as novas tecnologias digitais não são uma condição necessária para a adoção de modalidades contratuais que negam a condição de assalariamento.

Por exemplo, no Brasil, empresas de todos os setores contratam indivíduos por meio de arranjos comerciais como se eles fossem uma empresa de apenas uma pessoa (os conhecidos "PJs"). Salões de beleza, por sua vez, alegam que apenas "alugam" assentos para os(as) cabeleireiros(as) trabalharem para eles. As chamadas consultoras de empresas de cosméticos — na verdade, vendedoras —, classificadas como autônomas, passam de I milhão no país (ABÍLIO, 20I4).

Vejamos, resumidamente, alguns casos de gestão do trabalho que negam o assalariamento e antecedem (mas se mantêm) à chamada "plataformização".

\section{I.I As "cooperativas" de trabalho}

No Brasil, nas décadas de 1990 e 2000, houve uma proliferação das chamadas cooperativas de trabalho. Supostamente, eram entidades com associados que prestavam serviços de qualquer natureza, sem subordinação, a empresas contratantes.

Houve muitas investigações sobre esse fenômeno em todo o país e em diversos setores. Um caso que ilustra bem esses arranjos ocorreu numa empresa petroquímica na Bahia (FILGUEIRAS, 20I2). A empresa fazia a seleção dos supostos cooperados que laboravam em sua planta, contradizendo o caráter associativo da suposta cooperativa. Esta apresentava os currículos de trabalhadores, e a petroquímica selecionava os que iriam laborar. Constava no próprio contrato entre empresa e cooperativa uma cláusula que concedia à petroquímica a prerrogativa para selecionar quem poderia ou não trabalhar em sua planta, evidenciando que o objeto da relação era o trabalho de pessoas específicas. Ademais, parte dos trabalhadores já estava na petroquímica, executando os mesmos serviços que continuaram a realizar depois de "cooperados". Eles trabalhavam na planta havia anos, como empregados contratados por meio de uma empresa interposta.

A petroquímica, mediante contrato firmado com a "cooperativa", determinava controles, inclusive de frequência e horário sobre o trabalho dos supostos cooperados. Segundo o contrato, a petroquímica avaliava, "entre outros critérios, a apresentação, a pontualidade, o comportamento, a cortesia e a cordialidade" dos trabalhadores contratados por intermédio da cooperativa (FILGUEIRAS, 2012).

O uso dessas "cooperativas" não se restringiu ao Brasil. Na Espanha, por exemplo, elas se destacam entre as entidades contratadas no setor dos frigoríficos, 
representando cerca de $20 \%$ do total de ocupados no setor ${ }^{3}$ (3). Nos anos 1990 e 2000 , as "cooperativas" foram rapidamente adotadas (ou impulsionadas) pelos próprios frigoríficos. Os sócios das "cooperativas" são pagos apenas quando contratados pelas empresas (sendo declarados ao INSS como autônomos). Se estão sem trabalhar, não implicam qualquer custo à empresa ou à cooperativa, engendrando um mecanismo de gestão completamente flexível (a la carta) de um importante contingente de trabalhadores para os frigoríficos (RIESCO-SANZ, 2020).

Os sócios das "cooperativas" não participam (nem sabem) dos acordos firmados com as empresas. A inscrição como autônomo não é uma opção efetivamente voluntária, pois representa, comumente, a única forma de conseguir trabalhar no setor. Parar de trabalhar também não é uma decisão do "cooperado", mas da demanda por força de trabalho do frigorífico. As condições de trabalho são unilateralmente definidas pelas empresas. Não bastasse isso, o regime disciplinar imposto aos "cooperados" pelos frigoríficos é muito mais rígido do que o relativo aos empregados contratados formalmente (cerca de IO\% sofrem sanções a cada ano, contra 0,I5\% no total do setor) (RIESCO-SANZ, 2020).

Esses "cooperados" têm seu trabalho demandado, determinado e controlado diariamente pelos frigoríficos sem fazer parte da estrutura formal das empresas. São estas que, de fato, exercem, a todo momento, a organização e o controle do processo produtivo e de trabalho, desde a seleção dos "cooperados" até a organização da produção, qualidade e ritmo de trabalho (RIESCO-SANZ, 2020).

\section{I.2 Os self-employed do setor da construção no Reino Unido}

A construção é um dos setores que mais empregam no Reino Unido: abarcava cerca de 2 milhões de trabalhadores em 2015. E também se destaca pelo número de autônomos: $39 \%$ do total de empregos no setor, que correspondem a $20 \%$ de todo o trabalho "autônomo" no Reino Unido, segundo dados oficiais.

As empresas geralmente contratam trabalhadores classificados como autônomos por meio de agências de emprego ou utilizando "empresas guarda-chuva" (pessoas jurídicas utilizadas para intermediação). Apesar de diferenças formais, os casos que investigamos compartilham uma natureza comum: a força de trabalho continuava sendo gerenciada pela empresa contratante. A principal diferença entre empregados ou autônomos nos canteiros de obras estava simplesmente na forma pela qual eles eram contratados.

Por exemplo, em um canteiro de obras em Londres que visitamos em 2015, semelhante à maioria dos locais de trabalho desse tipo no Reino Unido, de acordo com outras fontes, havia 90 trabalhadores. No entanto, a construtora contratou diretamente apenas 5 deles; uma terceirizada contratou Io eletricistas, I5 eram empregados de agências e 60 foram contratados por agências como autônomos. Alguns desses trabalha-

3 As ponderações a seguir, sobre as "cooperativas" na Espanha, buscam sintetizar aspectos do minucioso estudo realizado por Riesco-Sanz (2020). 
dores autônomos, contratados por agências, trabalhavam há anos na mesma empresa. Os funcionários formais eram engenheiros, supervisores e os que estavam no topo da hierarquia funcional, determinando o que, onde, quando e como o trabalho seria realizado. Para exemplificar como as atividades foram organizadas, os operadores de guindastes, com contratos por conta própria, foram obrigados pela empresa a trabalhar dez horas por dia, seis a mais do que a previsão legal.

Em 20I6, a Câmara dos Comuns publicou um briefing paper sobre o tema, trazendo algumas informações sobre o uso do trabalho "autônomo" por empresas como estratégia para minar o direito do trabalho:

Em maio de 2008, a Union of Construction, Allied Trades \& Technicians (Ucatt) publicou um relatório da Universidade de Essex. O autor sugeriu que cerca de $30 \%$ da força de trabalho - 375.000 a $425.000-$ estava incorretamente envolvida como autônoma”. (tradução nossa)

De acordo com pesquisa realizada pela Flex (Focus on Labor Exploitation):

No setor de construção, há um uso amplo do trabalho autônomo como a modalidade de contratação mais usada. Trabalhadores autônomos têm direitos significativamente menores do que aqueles que são empregados diretamente por uma empresa. $\mathrm{O}$ antigo sindicato dos trabalhadores do setor da construção, Ucatt — agora fundido com a Unite afirma que existe um vínculo direto entre esses arranjos empregatícios e a exploração, e são muitos os casos em que os funcionários não estão trabalhando de fato para si mesmos (FLEX, 20I7, p. 8, tradução nossa).

Mais do que sugerir uma mera modificação na natureza das relações de trabalho nos canteiros de obras, os indícios, muito fortes, são de que a disseminação do trabalho autônomo no setor de construção britânico esteja estritamente relacionada a estratégias para gerenciar a força de trabalho negando a condição de assalariamento.

\section{I.3 Os caminhoneiros "autônomos"}

Motorista realmente autônomo é o que presta serviços para diferentes clientes, sem depender, nem estar subordinado a nenhum deles. Por exemplo, autônomo é aquele motorista que faz carretos de mudança para pessoas físicas diversas. Existem muitos trabalhadores com esse perfil, mas eles não são a maioria, nem os protagonistas do transporte de cargas no Brasil.

Centenas de milhares de motoristas supostamente autônomos (muitas vezes contratados como pessoas jurídicas) trabalham sempre para a mesma empresa e com exclusividade, em horário e com preços de frete unilateralmente impostos pela contratante. $\mathrm{O}$ pagamento desses motoristas depende exclusivamente do número de

4 Esta análise dos caminhoneiros "autônomos" é uma síntese da investigação de Filgueiras e Krein (2018). 
fretes, e seu trabalho é meticulosamente monitorado por satélite/GPS. As empresas também dirigem as atividades impondo prazos exíguos e multas para atrasos.

Ao contratar motoristas sem admitir sua condição de empregadoras, as empresas não cumprem nenhum direito trabalhista. Assim, tornam a vida desses trabalhadores completamente insegura, sem sequer uma renda mínima (salário básico) para sobreviver. O frete, que, de fato, constitui o salário desses trabalhadores no Brasil, não obedecia a qualquer parâmetro mínimo até a greve de 20I8. Também não há descanso remunerado, férias etc. $\mathrm{O}$ motorista se sente completamente dependente da execução de cada serviço, e por isso tende a trabalhar mais e descansar menos.

Após auditorias realizadas em apenas 9 empresas de transporte, em 2012, a Fiscalização do Trabalho identificou 472.606 jornadas de trabalho superiores a Io horas por dia. Segundo o órgão, a maioria dos acidentes envolvendo caminhões estava relacionada ao cansaço por jornadas excessivas. Não parece ser coincidência que, em pesquisa da própria CNT (20I6), só 23,3\% dos motoristas entrevistados ditos autônomos afirmaram estar satisfeitos e cumprindo as normas de descanso, e 65\% disseram não cumprir a lei, enquanto entre os motoristas empregados, $67 \%$ estavam satisfeitos e 51,7\% afirmaram cumprir os descansos previstos na lei. Apenas 21\% dos autônomos disseram que a flexibilidade de horário era um ponto positivo do trabalho.

A questão, do ponto de vista da gestão do trabalho, é que o trabalhador contratado como autônomo tende a ser ainda mais subordinado à empresa, pois sua relação é completamente precária e cada frete pode ser o último. À negação dos direitos trabalhistas se soma a transferência dos custos dos insumos (combustível, pneus, manutenção etc.) aos "autônomos". Desse modo, além de não ter renda certa, os motoristas têm de cobrir os custos inerentes à atividade, radicalizando sua insegurança. As empresas gastam menos, correm menos riscos e têm conseguido trabalhadores mais dóceis laborando em seu benefício. Em suma, há uma série de evidências da completa falta de autonomia desses "autônomos".

\section{I.4 O trabalho "integrado" 5}

Uma das "novas" formas de trabalho mais comuns no Brasil, particularmente nas atividades rurais, é a chamada "produção integrada". Em suma, o "integrado" é um pequeno agricultor (muitas vezes proprietário formal da terra) que assina um contrato de exclusividade para realizar alguma atividade que faz parte dos negócios de uma empresa, por exemplo, plantar tabaco para uma empresa de cigarros.

Essa "produção integrada" não é um mero monopsônio, uma vez que o processo de trabalho e produção realizado pelos trabalhadores integrados é controlado pelo chamado comprador único. As atividades realizadas pelos "integrados" fazem parte do negócio da empresa. Esta, entre outras coisas, fornece matérias-primas e insumos, impõe os padrões técnicos da atividade, normalmente financia instalações e

5 Esta análise dos "integrados" é uma síntese da investigação de Filgueiras (2013). 
é dona dos produtos finais (tabaco, ovos, aves, porcos etc.). O trabalhador integrado deve atender exclusivamente às demandas da empresa, entregando-lhe a produção no momento e nas condições exigidas pelo contratante.

Os trabalhadores "integrados" possuem uma renda totalmente flexível (depende exclusivamente dos resultados da produção), que é dividida com suas famílias, sem salário mínimo garantido nem férias remuneradas ou pagamento de horas extras, mesmo trabalhando todos os dias da semana. Um estudo realizado no setor avícola da Bahia (FILGUEIRAS, 20I3), constatou que o trabalho infantil se encontrava generalizado - um mecanismo adotado pelo trabalhador integrado para evitar a corrosão da renda familiar já escassa, o que também parece ser comum na produção de tabaco na região Sul (BRASIL, 2007). Desrespeito flagrante aos parâmetros mínimos das normas trabalhistas foi detectado na produção de ovos e em galpões de frangos, uma realidade que também parece ser frequente no resto do país, incluindo casos análogos à escravidão.

O modelo de "integração" é um instrumento essencial para o exercício do controle e exploração do trabalho nessas empresas. Como o assalariamento não é admitido, o direito do trabalho é negado e os trabalhadores são obrigados a trabalhar por mais horas e mais intensamente, todos os dias de forma ininterrupta, para garantir uma renda mínima necessária para a sobrevivência.

Enfim, esses são apenas alguns exemplos das "novas" formas de trabalho. Em todos eles, apesar de serem rotulados e contratados como autônomos (e/ou PJs, cooperados etc.), os trabalhadores são sistematicamente submetidos e controlados pelas empresas, sujeitando-se à vontade dos contratantes de forma ainda mais intensa do que aquela exercida em relação aos empregados formais.

As empresas negam deliberadamente o status de emprego assalariado para seus trabalhadores como uma ferramenta-chave para gerenciar seu processo de trabalho e produção. Ao afirmar que seus trabalhadores não são empregados, as empresas tentam reduzir limites à exploração, recusando direitos trabalhistas e inibindo a ação contestatória individual ou coletiva. A precarização torna os trabalhadores ainda mais submetidos às exigências das empresas. Ao precarizá-los (negando-lhes direitos e garantias) e transferir a eles os riscos, as corporações os tornam mais vulneráveis e menos propensos a resistir às determinações empresariais, acentuando, inclusive, a subsunção do trabalho ao capital. 


\section{2. "Plataformas" e "aplicativos"}

Nos últimos anos, têm se disseminado termos para definir transformações nos arranjos empresariais e no mundo do trabalho que estariam associadas ao uso das novas tecnologias da informação e comunicação (TICs): gig economy, platform economy, sharing economy, crowdsourcing, on-demand economy, uberização, crowdwork, trabalho digital, entre outros.

Por exemplo, a partir da forma de canalização e distribuição das atividades laborais, De Stefano (20I7) apresenta uma definição que pode englobar platform economy, gig economy e collaborative economy. Para o autor, nessas atividades o trabalho seria contratado ou realizado através das TICs, podendo ser efetuado digitalmente (crowdwork) ou presencialmente (on-demand). É frequente também a ideia de que o objetivo das "plataformas" e "apps" seria conectar a demanda de clientes por serviços específicos com a oferta desses serviços por trabalhadores provedores (THE HAMILTON PROJECT, 20I5). Nessa mesma direção, outra definição mais ampla de platform economy como intermediação contempla tanto serviços quanto bens e ativos a serem vendidos (FARELL; GREIG, 20I6) 6 .

A análise também pode ser feita numa perspectiva que relaciona transformações na estrutura empresarial e do trabalho. Nesse caso, as plataformas digitais significariam uma mudança fundamental no processo de outsourcing, que permitiria aos trabalhadores superar as barreiras dos mercados de trabalho locais para potencialmente realizar tarefas de qualquer lugar do mundo para qualquer lugar do mundo (GRAHAM et al., 20I7). Crowdwork, work on demand e digital labour também podem aparecer como sinônimos, como em Chesalina (20I7), para a qual a platform economy estaria acompanhada pela ascensão de novas formas de emprego, não mais caracterizadas pela transferência de atividades de uma empresa para agentes específicos, mas para um grande número de indivíduos ou organizações indefinidas.

Em que pesem as diferentes definições, essas terminologias pretendem identificar fenômenos que possuem as seguintes semelhanças: I) contatos on-line entre produtores/provedores e consumidores, trabalhadores e empresas; 2) uso de aplicativos ou plataformas para acesso em computador ou em instrumentos móveis

6 Neste texto, priorizamos análise das plataformas e aplicativos em que os trabalhadores(as) oferecem sua força de trabalho, deixando de lado aqueles em que são ofertados bens, que merecem um exame específico. 


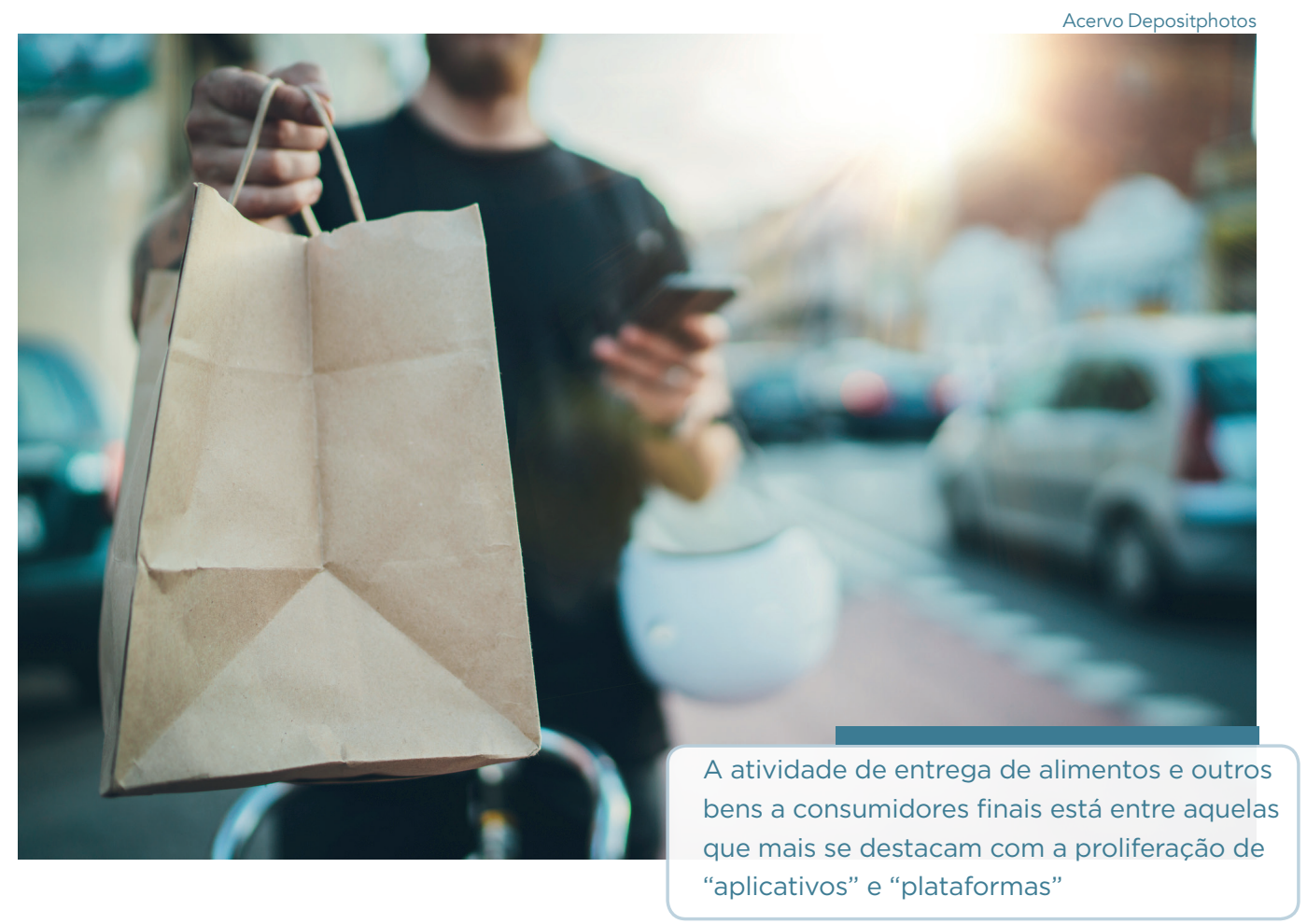

de comunicação; 3) uso intensivo de dados digitais para a organização e gestão dessas atividades; 4) relações estabelecidas por "demanda” (ou seja, os arranjos são feitos por produto, sem garantia de continuidade).

A posição que parece predominar é a de que essas transformações têm sido benéficas para quem trabalha, dentre outras razões, porque permitiriam que as restrições de oferta de serviços especializados por questões geográficas fossem reduzidas, facilitando a busca por oportunidades de renda para trabalhadores, independentemente da sua localização (KITTUR et al., 20I3). Ou, ainda, de que as plataformas e aplicativos tornariam a conexão e comunicação entre provedores de serviços e consumidores mais fácil e dinâmica, constituindo mercados on-line que facilitariam os negócios para ambos (MANYIKA et al., 20I6).

As corporações alegam que: I) são empresas de tecnologias digitais; 2) fazem a intermediação de atividades nas quais trabalhadores oferecem serviços de forma autônoma; 3) eliminam a subordinação, alegando liberdade para trabalhar quando, onde e como quiserem; 4) no caso mais extremo do novo adeus à classe trabalhadora, as empresas alegam que os trabalhadores seriam seus clientes, que pagariam uma "taxa" pelo uso do "aplicativo" ou "plataforma".

\subsection{Os entregadores, couriers ou repartidores}

A atividade de entrega de alimentos e outros bens a consumidores finais está entre aquelas que mais se destacam com a proliferação de "aplicativos" e "platafor- 
mas”. Em 20I5, no Reino Unido, vivenciamos um período de transição da gestão dos couriers por rádio para o uso de aplicativo. Entrevistamos trabalhadores vinculados a seis empresas, e analisamos documentos e equipamentos. Praticamente todos os trabalhadores do setor eram formalmente contratados pelas empresas como autônomos e sem garantia de pagamento mínimo. Com isso, em vez de ter mais flexibilidade, os entregadores tendiam a trabalhar mais e descansar menos do que o trabalhador médio, pois não tinham segurança no emprego e precisavam se esforçar para tentar compensar a baixa remuneração recebida por cada entrega. Eles não recebiam férias remuneradas nem qualquer renda quando estavam doentes ou sofriam algum acidente de trabalho.

A situação desses entregadores chamou a atenção da imprensa. Alguns dos trabalhadores que entrevistamos pessoalmente em Londres foram abordados para essas reportagens. Por exemplo, Mario Gbobo, que sofrera uma lesão grave no braço ao cair da bicicleta, conversou com a BBC sobre o acidente: "O pacote que eu carregava estava seguro, mas eu não estava [...] Alguém veio e pegou o pacote. Eu tive de me defender e acabei voltando ao trabalho antes que a lesão sarasse, porque precisava do dinheiro". Outro entregador, Andrew Boxer, afirmou: "Eu sou um caso típico, trabalho para uma empresa por cerca de 50 horas por semana. Eles me dizem o que fazer e quando e como fazê-lo" (COLEMAN, 20I6, tradução nossa).

Como sabemos, essas empresas de entrega passaram a se apresentar como "aplicativos" e se tornaram tendência mundial. Na Espanha, a condição de autônomo imputada aos trabalhadores contrasta com as ordens que recebem, como sobre o modo de realizar as entregas e lidar com o cliente, ou a de não recusar pedidos, sob pena de dispensa. Conforme apurado pela Justiça e pela Inspeção do Trabalho, as empresas

Não só detalham múltiplos aspectos acerca de como o trabalho deve ser realizado, mas também regras de comportamento são estabelecidas com proibições expressas ("como se disse em várias ocasiões, você é a cara da empresa [...]. Não se pode entrar com o capacete na cabeça nem no restaurante nem nas casas dos clientes"), além de restrições no que respeita à rejeição de pedidos ("A opção de rejeitar um pedido só existe em casos extremos [...]. Aqueles que rejeitarem pedidos de forma continuada não terão garantia dos dois pedidos por hora oferecidos pelo nosso sistema. Além disso, se você insistir nessa atitude de forma recorrente, a Deliveroo dispensará seus serviços"). (MADRID, 2019, tradução nossa)

Essa subordinação é extremamente similar à detectada no Brasil (FILGUEIRAS; ANTUNES, 2020). A flexibilidade, também por aqui, é apenas retórica. Nas entregas com bicicletas, pesquisa da Aliança Bike (PERFIL, 20I9), realizada em 2019 com 270 entregadores, indica que $57 \%$ trabalhavam todos os dias, e $55 \%$, IO ou mais horas por dia (apenas $25 \%$ trabalhavam menos do que 8 horas diárias). São resultados parecidos com 
pesquisa realizada no mesmo ano em Salvador, em que a jornada média mensurada foi de Ioh23min por dia, durante 6 dias na semana (FILGUEIRAS; PEREIRA, 20I9).

\subsubsection{Os tradutores}

A tradução é um dos muitos serviços oferecidos via internet. As empresas proprietárias da "plataforma" supostamente fazem a mediação entre clientes e tradutores. Os tradutores seriam autônomos que comandam seus próprios negócios, usando a plataforma para alcançar clientes. No entanto, a imagem real está longe dessa descrição superficial.

Em Londres, entrevistamos um tradutor que trabalha com esse tipo de arranjo. Ele nos deu acesso a e-mails e documentos que demonstram como o processo de trabalho está organizado, engendrando indícios suficientes para analisar a dinâmica geral desse setor. Em resumo, a empresa contrata um grupo de tradutores que, em princípio, podem trabalhar para outras empresas. Para ingressar nesse pool, o tradutor deve concluir um teste, enviar suas credenciais e assinar um contrato e outros documentos. Quando esse procedimento estiver concluído, toda vez que houver um pedido de tradução, os trabalhadores recebem um e-mail com um preço inicial a ser negociado. Quem primeiro oferecer um preço considerado satisfatório pela empresa ganha o serviço. Segundo o tradutor entrevistado:

É como uma versão acelerada e globalizada, just in time, do que existia anteriormente [...] O processo se tornou muito mais automatizado. Isso significa que, quanto mais participação de mercado uma empresa tiver, mais seus tradutores estarão alertas 24 horas por dia, sete dias por semana, para responder a qualquer demanda por serviço. Assim, você pode gastar muito tempo fazendo lances para serviços, mas não os obter (a menos que reduza sua remuneração). Financeiramente, é uma corrida para o fundo do poço.

A empresa seleciona quem pode ser contratado para formar o pool e, em seguida, organiza o processo de trabalho por meio de um leilão entre os trabalhadores para escolher quem receberá cada trabalho. Por fim, define quando e como a tradução deve ser feita, conforme podemos ver no seguinte e-mail:

Como você está hoje? Espero que esteja tudo bem. Temos uma tradução rápida de espanhol > inglês (EUA) para I.200 palavras e precisamos da sua ajuda!

JUSTIFICATIVA: clínica; INSTRUÇÕES: siga o formato da fonte o mais próximo possível! Por favor, corresponda ao formato da data. Por favor, indique qualquer texto que esteja ilegível entre colchetes (ou seja, "[ilegível]"); copie/ cole logotipos; copie/cole números e qualquer texto em inglês; redija todas as informações do paciente. Por favor, indique manuscrito em itálico e uma nota entre colchetes, ou seja, "[hw]". 
ENTREGUE: um documento do Word traduzido.

PRAZO DE TRADUÇÃO: IIh EST, quarta-feira, 22/7. Informe-nos se você está disponível para este trabalho.

O trabalho mencionado nesse e-mail foi oferecido às Ioh23 e teve de ser realizado até as I6h. Conforme declarado pelo tradutor, esse é um e-mail típico enviado pela empresa. Para ele, o significado do processo é: "Você deve largar tudo e fazê-lo agora! O objetivo é obter um resultado máximo (ou seja, a concorrência mais feroz) de nós, o grupo global de tradutores".

Standing (20I6) também descreveu essa estratégia de gestão, que ele chama de pool de trabalho da multidão:

O que acontece é que as empresas de plataforma contratam pessoas para realizar determinados trabalhos para as empresas e, por sua vez, designam solicitantes de mão de obra para contratar trabalhos para pessoas convidadas a competir em um leilão holandês. Os solicitantes anunciam que há muitas tarefas disponíveis para licitação, com prazo estipulado, e que a licitação será encerrada em, digamos, cinco dias. Frequentemente, o solicitante anuncia desde o início uma taxa máxima pelo serviço. Em seguida, os taskers podem tentar realizar o maior número de tarefas que acharem viável a um preço que acharem certo. No final, os solicitantes selecionam os lances mais baixos. Então, alguém em Boston pode estar competindo com alguém de Bangalore ou Acra. Isso é péssimo, já que os mais inseguros tenderão a oferecer os preços mais baixos. Como eles não sabem quantos estão se oferecendo ou onde estão, podem acreditar que a concorrência seja mais intensa do que é. Para a agência que contrata, isso é o ideal. E o tasker não tem garantia de que será pago. Se um corretor, com sede em Nova York, decide que um tasker em Dakar não fez algo bem o suficiente e se recusa a pagar, na prática o tasker não tem meios de reparação.

A descrição de Standing mostra como opera esse mecanismo de contratação de trabalhadores que se tornou cada vez mais comum em vários tipos de atividades. Os lucros dessas empresas estão diretamente ligados à insegurança e à precariedade daqueles que precisam aceitar as tarefas para garantir sua sobrevivência. Nossa divergência em relação ao argumento de Standing é que a solução proposta por ele - a introdução de uma renda básica universal como forma de eliminar a coerção econômica imposta àqueles que precisam aceitar as tarefas pressupõe a impossibilidade de regular esses empregos por meio do direito do trabalho. Não se trata de negar a importância de uma renda básica, mas é precisamente esse ponto - a necessidade de reconhecimento legal da condição de emprego - que deve estar no centro da luta política, e não qualquer imposição técnica dos dispositivos utilizados. 


\subsubsection{Os motoristas}

Provavelmente, o caso mais famoso de operação de "aplicativos" esteja no setor de transporte, particularmente o de passageiros. Em nível mundial, tem destaque a Uber, que se apresenta como um aplicativo que presta serviços a motoristas. Em uma ação judicial no Reino Unido, o modelo foi assim descrito: "O argumento da Uber era o de ser uma empresa de tecnologia, e que não fornecia um serviço de transporte para os clientes - apenas os colocava em contato com os motoristas"7.

No Brasil, os motoristas da Uber não possuem contrato formal com a empresa, mas devem cumprir uma série de requisitos para ser admitidos. Apesar da retórica da flexibilidade do horário de trabalho, quando a Uber inicia sua operação em uma cidade, atrai motoristas fazendo pagamentos fixos pela realização de jornadas de trabalho. As tarifas pagas aos motoristas variam de acordo com a hora do dia e a região da cidade, levando-os a trabalhar de acordo com a demanda da empresa. A Uber impõe unilateralmente as taxas que receberá por cada viagem, que também oscilam por cidade, período do ano etc. O comportamento dos motoristas deve seguir as diretrizes da empresa, relacionadas ao cliente e às condições do carro. Os clientes pagam diretamente à Uber (quando pagam ao motorista, o valor é deduzido das próximas viagens). Os motoristas não podem organizar viagens diretamente com os clientes nem recusar animais, levar outra pessoa no veículo, executar outros serviços enquanto estiverem com passageiros, compartilhar o carro para usar seu registro Uber ou solicitar informações particulares aos passageiros, entre vários outros requisitos que devem ser cumpridos no trabalho. Embora tratado como uma empresa, o motorista não pode fazer uso de sua propriedade (o carro) da forma que lhe convenha.

A Uber avalia permanentemente os motoristas por meio dos clientes, que pelo aplicativo avaliam o motorista no final do percurso. A empresa deixa claro que "atitudes que prejudicam a plataforma, usuários ou outros parceiros também podem levar à desativação", mesmo que não estejam pré-listadas em contrato ${ }^{8}$. Ou seja, o trabalhador pode ser demitido por qualquer motivo que a Uber considere aplicável.

\subsection{Menos assalariados ou ainda mais subordinados?}

Filgueiras e Antunes (2020) apontam ao menos II medidas adotadas por empresas que se apresentam como "plataformas" e "aplicativos" para o controle dos trabalhadores.

As empresas: I) determinam quem pode trabalhar para elas: se são mais ou menos exigentes na admissão (cadastro), isso não muda o fato de que são elas que decidem de acordo com suas conveniências (estratégias); 2) delimitam o que será feito, seja uma entrega, um deslocamento, uma tradução: logados nas "plataformas" e "aplicativos", os trabalhadores não podem prestar serviços não contemplados por elas; 3) definem

7 https://www.theguardian.com/business/2016/jul/20/uber-driver-employment-tribunal-minimum-wage

8 Informações obtidas em entrevista com motoristas e por meio do site da Uber no Brasil: www.parceirosbr. com/politicas-e-regras 
que trabalhador realizará cada serviço (no mínimo, definindo quais trabalhadores podem concorrer pelo serviço) e não permitem captação de clientes; ou seja, as empresam contratam (ou não) o serviço de cada trabalhador (as notas dos clientes são apenas um instrumento para a decisão de alocação, que é da empresa); 4) delimitam como as atividades serão efetuadas: isso ocorre nos mínimos detalhes, seja em relação ao trajeto, ao estado do veículo e até ao comportamento dos trabalhadores diante dos clientes - a Uber recentemente desenvolveu, por exemplo, o silent mode, para que o usuário não permita que o(a) motorista fale durante o trajeto; 5) determinam o prazo para a execução do serviço, seja para as entregas, para realização das traduções etc;

6) estabelecem, de modo unilateral, os valores a serem recebidos: essa é uma variável-chave, porque os pagamentos são manipulados para dirigir o comportamento dos trabalhadores. Aqui entram os algoritmos, que nada mais são do que programas, comandados pelas corporações, para processar grande volume de informações (tempo, lugar, qualidade) que permitem direcionar a força de trabalho segundo a demanda a qualquer momento. Há uma espécie de "leilão invertido" que coloca todos os trabalhadores em concorrência permanente, a cada novo serviço a ser executado. As "plataformas" intencionalmente procuram formar um estoque de trabalhadores disponíveis ${ }^{9}$ (8), criando uma espécie de "mercado de trabalho" no interior de cada empresa, que visa ao enfraquecimento do poder de barganha dos trabalhadores e ao rebaixamento salarial. Essa baixa remuneração é um mecanismo importante para a imposição de longas jornadas aos trabalhadores, pois, para sobreviverem, eles arcam com o conjunto dos custos e contraem dívidas (como a compra ou aluguel dos carros) que dependem dos salários para serem quitadas. De fato, como consta em (MPT, 20I8), quanto menor a tarifa paga, mais horas de trabalho serão necessárias para garantir a sobrevivência do indivíduo.

As empresas também: 7) determinam como os trabalhadores devem se comunicar com elas: por exemplo, vedam usar redes sociais ou outros meios que não os estipulados por elas para reclamar ou fazer críticas; 8) pressionam os trabalhadores a ser assíduos e não negarem serviços demandados; 9) também os pressionam a trabalhar mais tempo com o uso de incentivos, sendo comuns as chamadas promoções, que atuam como metas com horários a ser cumpridos pelos contratados, para incitar que fiquem mais tempo à disposição das empresas: essa medida é usada, por exemplo, pela Uber em períodos de férias de fim de ano, como forma de garantir a regularidade do serviço - neste caso, o trabalhador(a) recebe por número de viagens pré-estabelecido, independentemente da duração ou distância;

Io) usam o "bloqueio" para ameaçar os trabalhadores, que consiste em impedir que eles exerçam sua atividade por tempo determinado, por inúmeras razões definidas pelas "plataformas"; II) utilizam a possibilidade de dispensa a qualquer tempo, sem necessidade de justificativa nem qualquer espécie de aviso, como um mecanismo

9 Para isso, muitas empresas, quando iniciam suas atividades, pagam aos trabalhadores pelo tempo que ficam à sua disposição e os remuneram acima da concorrência. 
de coerção e disciplinamento: isso aparece patentemente nas entrevistas e nos "termos de uso" de diversas empresas.

Vale destacar que, quando os trabalhadores adoecem, descansam ou tiram férias, têm seus instrumentos de trabalho parados, e seus rendimentos são zerados. Assim, para sobreviver e manter seu vínculo de trabalho, eles precisam trabalhar por longas horas, suprimir descansos, intensificar jornadas e agir de estrito acordo com o que é determinado pela empresa.

Algumas contradições emergem dessas "novas" formas de trabalho. Primeiro, com a individualização dos serviços e da remuneração, a exploração se torna mais explícita - sabe-se quanto cada trabalhador produz e qual o percentual apropriado pela empresa, que está rigorosamente quantificado nas plataformas digitais.

Ademais, o controle do capital se reforça e se reproduz com a ideia de que os trabalhadores estão se autogerindo (CASTRO, 2020). Contudo, as plataformas digitais controlam todo o processo, determinam os formatos exatos dos contratos de trabalho, pagam, mobilizam, ameaçam e dispensam. Os trabalhadores são induzidos a adotar os comportamentos dirigidos pelas empresas, não lhes cabendo alternativa se querem trabalhar. $O$ fato de se submeterem a essas condições não significa que a iniciativa, o controle e a autonomia das atividades estejam em suas mãos.

No final das contas, os trabalhadores "digitais" são menos livres e estão mais submetidos ao capital do que os assalariados reconhecidos com tais. Isso porque eles sofrem uma dupla coerção para se subjugar. Além da coerção tradicional do mercado de trabalho (externa), que é a ameaça de dispensa comum a qualquer empregado, eles também sofrem uma coerção interna, pois, mesmo com contrato, estão sob permanente ameaça de não ter renda (e por fim, mesmo quando conseguem um serviço, não têm nenhum direito respeitado). A tecnologia entra nesse cenário para aperfeiçoar esse controle, pois se sabe precisamente, e em tempo real, quem está fazendo o que, de que modo, por quanto tempo, em qual velocidade etc. Assim, a grande novidade na organização do trabalho introduzida pelas novas TICs é permitir que as empresas utilizem essas ferramentas como instrumental sofisticado de controle da força de trabalho.

Em estratégias como as adotadas não apenas pelas "plataformas", mas também em arranjos como a "produção integrada", o que as empresas fazem é transformar os meios de produção e instrumentos de trabalho (veículos, instalações, computadores, terra etc.) em seu capital, sem a necessidade de propriedade formal sobre eles. As empresas podem controlar o processo de trabalho e produção por outros meios (por exemplo, monopolizando a interface com os clientes), em especial instrumentalizando a transferência dos riscos do negócio ao trabalhador (que arca com a compra ou aluguel de carros, motos etc. e sua manutenção). Nessa dinâmica, não ter a propriedade de carros, bicicletas, computadores e terras é uma grande vantagem para as empresas, pois elas não precisam imobilizar capital, e contam com trabalhadores mais inseguros e com menor probabilidade de contestar ordens. 
As empresas

apresentam

seus arranjos

intencionalmente

como "novos",

entre outros

motivos, para

evitar a legislação

trabalhista

Um ponto de vista, como o de Standing, que enfatiza a propriedade dos meios de produção pelo trabalhador, prioriza a formalidade e não o conteúdo real das relações. Vale lembrar a distinção entre a noção legal de propriedade e o poder efetivo sobre meios de produção feita por autores como Poulantzas (1977) e Bettelheim (1976). Nos casos discutidos aqui, as empresas não possuem direitos formais para gerenciar carros, bicicletas, computadores etc. No entanto, detêm a posse efetiva dos meios de produção em duas dimensões. Em primeiro lugar, os proprietários formais não definem os termos do contrato com os usuários. Para a pessoa que compra, o trabalhador é/representa a "empresa". O trabalhador tem que respeitar um código estabelecido pela empresa, não uma relação contratual entre ele e o usuário. Em segundo lugar, a empresa é capaz de controlar o conjunto de trabalhadores por meios como a manipulação das taxas, impondo condições para garantir a demanda e o suprimento de carros, bicicletas etc., além de suprir trabalhadores para realizar as viagens. Em muitos casos, a empresa participa do financiamento (ou financia) dos meios de produção aos trabalhadores para viabilizar a atividade. Em suma, a empresa não precisa de propriedade legal porque já tem sua posse efetiva. As análises, mesmo críticas, que desconsideram esse aspecto material objetivo, acabam por naturalizar o argumento politicamente orientado das empresas para deliberadamente contornar a proteção do emprego.

No que tange às TICs, elas ainda têm sido usadas para difundir a ideia de expansão das oportunidades de negócios para qualquer pessoa, engendrando uma espécie de neoempreendedorismo. O uso das tecnologias sugere uma aparente democratização dos meios de produção (basta ter um computador, carro ou mesmo bicicleta) para a produção "autônoma" de renda, seja como criador, seja como parceiro de uma startup: agora, mais do que nunca, seu sucesso "só depende de você". Isso é radicalizado quando as empresas alegam disponibilizar os apps ou as plataformas para pessoas que querem ofertar e melhorar "seus negócios", engendrando a ideia de que os trabalhadores são clientes das empresas. 
Além de dificultar a resistência individual e a ação coletiva, esses arranjos têm minado a regulação protetiva do trabalho pelo Estado. A narrativa que divulga essas "novas" formas de trabalho representa, na prática, um novo adeus à classe trabalhadora, mais radicalizado do que o primeiro, mas na mesma ideia nuclear: o emprego assalariado estaria perdendo sua relevância na sociedade Anteriormente, as previsões focavam-se no trabalho industrial; no entanto, agora tratam do emprego assalariado como um todo. Estaríamos experimentando novas maneiras de organizar o trabalho e a produção além do trabalho assalariado, em razão do crescimento do trabalho por conta própria, das "zonas cinzentas" e das relações indeterminadas, ou mesmo da transformação de trabalhadores em clientes. De todo modo, seriam relações inadequadas à regulação da legislação trabalhista.

\section{AS CONSEQUUÊNCIAS POLÍTICAS DO NOVO ADEUS}

A definição legal das "novas" formas de trabalho é uma questão política, não técnica. A maneira como essas relações são definidas impõe como serão reguladas e como as pessoas nelas inseridas irão trabalhar e viver. Essa é uma questão crucial que tem minado a qualidade de vida de milhões de trabalhadores nas últimas décadas.

A luta política em relação à regulação do trabalho assalariado é tão antiga quanto o próprio capitalismo. Acordos e compromissos que permitiram limites à mercantilização da força de trabalho são instáveis e expostos a constantes mudanças. Desde as últimas décadas do século XX, houve um fortalecimento internacional do que Dardot e Laval (20I6) chamaram de "a nova razão do mundo", isto é, o poder do neoliberalismo, que não se restringe à sua capacidade de realizar mudanças legais. Desde o início, ele pretende fomentar uma nova racionalidade com o objetivo de fazer com que todos pensem e ajam como se fossem empresas. Nesse sentido, é crucial evitar qualquer "neutralidade técnica" na afirmação de que "novas" formas de trabalho não são compatíveis com o direito do trabalho.

É importante enfatizar que existe uma diferença fundamental entre o trabalho assalariado e o conceito de empregado. O conceito de empregado é construído para regular uma relação de natureza política, e pode abarcar situações mais amplas ou ser mais estreito. Por exemplo, a lei pode indicar que o status de empregado é aplicável apenas a um indivíduo que trabalha para a mesma empresa mais de dez horas por dia, definindo aqueles que não estão nessa categoria como freelancers. A lei é uma relação social e pode ser definida de qualquer forma, desde que exista poder político para impô-la, independentemente do conteúdo efetivo das relações reguladas. Além disso, ela pode definir algo em uma direção hoje e mudar para outra direção amanhã, dependendo da luta política relacionada ao assunto em disputa.

Esse é precisamente o caso das "novas" formas de trabalho. As empresas apresentam seus arranjos intencionalmente como "novos", entre outros motivos, para evitar a legislação trabalhista. Elas nem sequer omitem essa intenção em certos con- 
textos, como em vídeos corporativos e eventos empresariais. Elas criaram e ajudaram a divulgar o discurso de "novas" formas de trabalho como parte de uma ofensiva para justificar as formas precarizantes de contratar trabalhadores. Esta é a racionalidade: evitar ser visto como empregador é uma das principais estratégias do capital para gerenciar o trabalho no capitalismo contemporâneo.

O impacto dessa narrativa nas legislações trabalhistas tem sido grande. Na Espanha e no Reino Unido, por exemplo, com base na aceitação da ideia de "zona cinzenta", foram adotadas formas de contratação com menos direitos do que os empregos típicos, chamados respectivamente de "autônomo dependente" e "worker". No Brasil, o trabalho "integrado", o "aluguel" de cadeira, os caminhoneiros "autônomos", todos foram objeto de leis anunciando que não forma vínculo de emprego a relação entre esses trabalhadores e seus contratantes. Em 20I7, a reforma trabalhista introduziu um artigo ampliando o conceito de trabalho autônomo (que pode servir a uma única empresa com exclusividade), buscando, portanto, reduzir o escopo de trabalhadores contemplados pela proteção da legislação trabalhista.

O novo adeus à classe trabalhadora também tem repercutido entre os próprios trabalhadores. Para eles, tem sido mais difícil construir identidades e se engajar em ações coletivas para confrontar um adversário fluido ou não identificado. $\mathrm{O}$ efeito ideológico é tão forte que muitas vezes os trabalhadores nem sequer se reconhecem como parte do processo produtivo do seu contratante e incorporam, por uma opção mediada desde o início pela coerção da sobrevivência, a figura do autônomo ou empreendedor.

Uma discussão civilizatória sobre as chamadas novas formas de trabalho precisa se basear em duas premissas principais:

1) Não devemos tomar como certos os nomes que as empresas declaram em contratos ou pressupor que estes definem o conteúdo real das relações. Dependendo do contexto, as empresas podem atribuir qualquer terminologia e impor qualquer condição ao contrato, incluindo a maneira como as atividades devem ser executadas, para favorecer seus interesses.

2) Não devemos confundir a maneira como o Estado regula o trabalho (que tem sido fortemente influenciada pelos interesses das empresas) com o conteúdo das relações efetivamente estabelecidas.

Para resumir, não recusamos inteiramente o conteúdo da literatura aqui criticada. Uma parcela dos trabalhadores pode negar sua identidade como assalariados e incorporar uma mentalidade de negócios, como se fossem "capitalistas de si mesmos". Devido às novas estratégias das empresas, que têm como aspecto central da gestão a negação do assalariamento, a construção da identidade coletiva pelos trabalhadores se torna mais difícil. Não é uma percepção incorreta da literatura, mas o resultado de uma longa batalha ideológica. No entanto, esse quadro não é suficiente para invalidar a regulação protetiva do trabalho. 


\section{NOTAS FINAIS: TÃO FÁCIL E TÃO DIFÍCIL}

Nas últimas décadas, enquanto a classe trabalhadora se enfraqueceu, o capital organizou uma estrutura de gestão que tende a reproduzir e reforçar essa debilidade. É irônico que, em um contexto de ofensiva maciça do capital e crescente subsunção do trabalho, estejamos testemunhando um novo adeus à classe trabalhadora.

Ao serem considerados como processo inexorável, tanto o antigo quanto o novo adeus compartilham um resultado político muito problemático, segundo o qual os trabalhadores protegidos pela lei fazem parte de grupos que estão desaparecendo e/ou são privilegiados. Esse entendimento obscurece a exploração do trabalho e o favorecimento aos reais empregadores, que se aproveitam da inobservância das obrigações legais.

Ainda assim, há sinais de resistência entre trabalhadores e instituições públicas no mundo. Por exemplo, documentos estatais do Reino Unido e da Espanha enfatizam o uso intencional do status de trabalho autônomo por empresas para minar os direitos e condições mínimas dos trabalhadores $^{10}$. Há também decisões judiciais, inclusive em cortes superiores da França, Espanha e Reino unido, que refutam a narrativa empresarial de que os trabalhadores de "plataformas" seriam trabalhadores por conta própria. Na Califórnia, uma lei abrangente foi recentemente aprovada para combater a utilização do assalariamento disfarçado em vários setores.

No Brasil, há muitos casos de reconhecimento do vínculo de emprego nas "novas" formas de trabalho (especialmente antes das "plataformas") pelas instituições públicas, embora não prevaleça um enfrentamento com a devida força (FILGUEIRAS, 20I2). Mais recentemente, com o argumento das TICs, há posições nos dois sentidos. Agora, contudo, parece se fortalecer a narrativa do novo adeus à classe trabalhadora, como evidenciam recentes decisões do Tribunal Superior do Trabalho (TST).

10 No Reino Unido, em 2018, a Gangmasters and Abuse Labour Authority (órgão público de regulação), destacou essa situação nos setores de limpeza, colheita de flores, lavagem de carros, processamento de alimentos e construção (GLAA, 2018). Na Espanha, também em 2018, a Inspeção do Trabalho identifica os falsos autônomos, trabalhadores verdadeiramente assalariados, como uma prioridade em sua atuação. 


\section{O novo adeus à classe trabalhadora} também tem repercutido entre os próprios trabalhadores. Para eles, tem sido mais difícil construir identidades e se engajar em ações coletivas para confrontar um adversário fluido ou não identificado

O caráter completamente político da regulação é explicitado pelas contradições da lógica elementar expressas na fundamentação de algumas decisões judiciais sobre o vínculo empregatício nas "novas" formas de trabalho, particularmente nas "plataformas". Ocorre que essas decisões, atendendo às demandas empresariais, negam o caráter empregatício das relações com base na suposta liberdade para os trabalhadores definirem suas jornadas de trabalho. Mesmo que essa alegação fosse verdadeira, as legislações de diversos países, como Reino Unido, Espanha e, mais recentemente, Brasil, foram alteradas, a pedido das empresas, justamente para permitir que elas contratem empregados que "podem" decidir quando irão aceitar ou não os serviços oferecidos, que são os conhecidos contratos de "zero hora" ou intermitentes. Ou seja, a permissão para contratar empregados sem lhes impor formalmente uma jornada fixa de trabalho foi uma conquista das próprias empresas.

Está ocorrendo uma luta pela regulação do trabalho. Não é uma dinâmica natural decorrente de qualquer ordem técnica ou organizacional. A Uber é um bom exemplo, novamente. A tecnologia subjacente que permite a operação do aplicativo já existia muito antes da empresa. O que não existia era a permissão legal para reunir dados pessoais e promover e gerenciar serviços de transporte sem a contratação formal de empregados. A “inovação” que importa aqui é principalmente legal, gerado por políticos e advogados, e não tecnológica.

No capitalismo, dar efetividade aos direitos previstos para a classe trabalhadora é um desafio central que constitui a própria história do movimento operário e do direito do trabalho. Desde os primórdios das normas de proteção ao trabalho, a luta do capital contra a aplicação delas é intensa. Agora, ao contrário do que usualmente tem sido anunciado, com o advento das novas TICs e seu uso pelas empresas na gestão e controle do trabalho, nunca foi tão fácil, do ponto de vista técnico, efetivar o direito do trabalho. As novas tecnologias tornam muito mais rápido, preciso e incontroverso identificar os trabalhos realizados, seus movimentos e duração, assim como o cumprimento de normas de proteção ao trabalho.

A identificação de todos esses aspectos da relação de emprego, antes dependente de testemunhas, papéis e inspeções in loco, agora se encontra minuciosa e de- 
talhadamente disponível na rede e nas bases de dados das empresas, para os trabalhadores tomados isolada ou coletivamente: jornadas de trabalho, descansos, pagamentos, tarefas etc. Para acessar essas informações, basta a algum órgão estatal requisitá-las. Isso já foi feito, por exemplo, em Nova York, apurando-se que a grande maioria dos motoristas em serviços de transporte de passageiros recebia menos do que o salário mínimo da cidade (PARROT, REICH, 20I8).

Também a efetivação das normas se tornou tecnicamente muito mais fácil. Em vez de audiências, compromissos, eventual uso da polícia, procura por bens etc., basta interpelar diretamente a plataforma, sob ameaça ou realização de bloqueio ou de intervenção em seu funcionamento. Impor limites de duração e intensidade de trabalho, e instituir descanso, férias, pagamentos mínimos e de horas extras e procedimentos de segurança do trabalho, entre outras obrigações, se torna muito simples e eficaz.

Justamente quando é mais fácil proteger o trabalho do ponto de vista tecnológico, mais difícil se torna politicamente implementar essa regulação, por conta do aprofundamento da assimetria de forças entre capital e trabalho, para a qual a retórica do novo adeus à classe trabalhadora tem contribuído fortemente.

De todo modo, apesar do contexto extremamente desfavorável à regulação protetiva do trabalho, o resultado desse processo não é inexorável. Parte essencial da resistência contra as formas flexíveis e precárias de contratar força de trabalho reside em uma mudança na assimilação da narrativa dos empregadores, cujos argumentos e designações sobre a organização da produção e do trabalho no capitalismo atual precisam ser repensados criticamente.

*Professor visitante da Universidade Complutense de Madrid e professor adjunto da Faculdade de Economia da Universidade Federal da Bahia (UFBA).

E-mail: fvitor@ufba.br

** Professor do Departamento de Sociologia do Instituto de Filosofia e Ciências Humanas da Universidade Estadual de Campinas (IFHC-Unicamp).

E-mail:saviomc@unicamp.br

O presente trabalho foi realizado com apoio da Coordenação de Aperfeiçoamento de Pessoal de Nível Superior (Capes); código de financiamento: 001.

This study was financed in part by the Coordenação de Aperfeiçoamento de Pessoal de Nível Superior (Capes — Brasil); finance code: 001.

Texto recebido em maio de 2020; aprovado em junho de 2020. 
ABÍLIO, Ludmila. Sem maquiagem: o trabalho de um milhão de revendedoras de cosméticos. São Paulo: Boitempo, 2014.

ANTUNES, Ricardo. Adeus ao trabalho?: ensaio sobre as metamorfoses e a centralidade do mundo do trabalho. São Paulo: Cortez, 1995.

BETTELHEIM, Charles. A luta de classes na União Soviética: Primeiro período (1917-1923). Rio de Janeiro: Paz e Terra, 1976.

BRASIL. Ministério Público do Trabalho. Ação civil pública com pedido de antecipação de tutela. Disponível em: http://actbr.org.br/uploads/arquivo/188 MPTPRxsouzacruz fumicultores.pdf. Acesso em: 1 maio 2011.

CASTRO, Viviane Vidigal de. As ilusões da uberização: um estudo à luz da experiência de motoristas Uber.. Dissertação (Mestrado em Sociologia) — IFCH, Unicamp, Campinas, 2020.

CAVALCANTE, Sávio. Classe média e modo de produção capitalista: um estudo a partir do debate marxista. Tese (Doutorado em Sociologia) — IFCH, Unicamp, Campinas, 2012.

CNI. A indústria e o Brasil: uma agenda para crescer mais e melhor. Brasília: Confederação Nacional da Indústria, 2010.

CNT. Pesquisa CNT: perfil dos caminhoneiros 2016. Brasília: Confederação Nacional do Transporte, 2016.

COLEMAN, Clive. Bike couriers launch legal fight over workers' rights. BBC News, Londres, 22 abr. 2016. Disponível em: <www.bbc.com/news/uk-36103978>. Acesso em: 8 jun. 2020.

DARDOT, Pierre; LAVAL, Christian. A nova razão do mundo: ensaio sobre a sociedade neoliberal. São Paulo: Boitempo, 2016.

CHESALINA, Olga. Social security for platform economy as a challenge for social security in Germany and in Russia: a comparative study. Spanish Labour Law and Employment Relations Journal, v. 7, n. 1-2, p.17-28, 2017. Disponível em: https://e-revistas.uc3m.es/index.php/SLLERJ/article/view/4433. Acesso em: 20 ago. 2019.

DE STEFANO, Valerio. Labour is not a technology - reasserting the declaration of philadelphia in times of platform-work and gig-economy. IUSLabor 2/2017. Disponível em: https://core.ac.uk/download/pdf/155003521.pdf. Acesso em: 10 nov. 2019.

DE STEFANO, Valerio. The rise of the "just-in-time workforce": on-demand work, crowdwork and labour protection in the "gig-economy". International Labor Office, Inclusive Labour Markets, Labour Relations and Working Conditions Branch, Conditions of work and employment series, n. 71, Geneva, 2016. Disponível em: http://www.ilo.org/wcmsp5/groups/public/---ed_protect/---protrav/---travail/documents/publication/wcms_443267.pdf. Acesso em: 18 mar. 2018.

FARRELL; Greig. Paychecks, Paydays, and the Online Platform Economy Big Data on Income Volatility.

[s.l.]: JP Morgan Chase \& Co Institute, 2016. Disponível em: https://papers.ssrn. com/sol3/papers.cfm?abstract_id=2911293 
FILGUEIRAS, Vitor Araújo. Estado e direito do trabalho no Brasil: regulação do emprego entre 1988 e 2008. Tese (Doutorado em Ciências Sociais) — FFCH, UFBA, Salvador, 2012.

Novas/velhas formas de organização e exploração do trabalho: a produção "integrada" na agroindústria. Mediações, Londrina v. 18, n. 2, p. 230-245, 2013.

. Regulação da terceirização e estratégias empresariais: o aprofundamento da lógica desse instrumento de gestão da força de trabalho. Cadernos do Ceas, Salvador, n. 239, p. 742-770, 2016.

; CAVALCANTE, Sávio Machado. What has changed: a new fare-

well to the working class?. Revista Brasileira de Ciências Sociais, São Paulo, v. 35, 2020. Disponível em: <www.scielo.br/scielo.php?script=sci_arttext\&pi$d=$ S0102-69092020000100512\&lng=pt\&nrm=iso\&tlng=en>. Acesso em: 8 jun. 2020.

FILGUEIRAS, Vitor Araújo; ANTUNES, Ricardo. Plataformas digitais, uberização do trabaIho e regulação no capitalismo contemporâneo. Revista Contracampo, Rio de Janeiro, v. 39, p. 27, 2020. Disponível em: http://periodicos.uff.br/contracampo/article/view/38901. Acesso em 10 jun. 2020

FILGUEIRAS, Vitor Araújo; KREIN, José Dari. A raiz da greve dos caminhoneiros e a regulação do trabalho. Revista IHU On-line, São Leopoldo, 29 maio 2018. Disponível em: <www.ihu.unisinos.br/78-noticias/579431-a-raiz-da-greve-dos-caminhoneiros-e-a-regulacao-do-trabalho>. Acesso em: 8 jun. 2020.

FILGUEIRAS, Vitor; PEDREIRA, Sara. Trabalho descartável: as mudanças nas formas de contratação introduzidas pelas reformas trabalhistas no mundo. Cadernos do CEAS, Salvador/Recife, n. 248, p. 578-607, set./dez., 2019. Focus on Labour Exploitation (FLEX), Tackling Exploitation in the UK Labour Market (2017)

GLAA. The nature and scale of labor exploitation across all sectors within the United Kingdom. Londres: Gangmasters and Labor Abuse Authority, 2018.

GORZ, Andre. Farewell to the working class. Londres: Pluto Press, 1982.

GRAHAM, Mark; HJORTH, Isis; LEHDONVIRTA, Vili. Digital labour and development: impacts of global digital labour platforms and the gig economy on worker livelihoods. European Review of Labour and Research. Vol 23, Issue 2, 2017.

ILO. World employment and social outlook 2015: the changing nature of jobs. International Labour Office. Geneva: International Labour Organization, 2015.

KITTUR, Aniket et al. The Future of Crowd Work. In Proceedings of the ACM Conference on Computer Supported Coooperative Work. February 23-27, 2013, San Antonio, Texas, USA. Disponível em: https://hci.stanford.edu/publications/2013/CrowdWork/futureofcrowdwork-cscw2013.pdf. Acesso em 25 mar. 2018.

LOBEL, Fabrício. Número de motoristas do Uber cresce dez vezes em um ano no Brasil. Folha de S.Paulo, São Paulo, 30 out. 2017. Disponível em: http://www1.folha.uol.com.br/ cotidiano/2017/10/1931013-numero-de-motoristas-do-uber-cresce-dez-vezes-em-um-ano-no-brasil.shtml Acesso em 10 out. 2018.

MANYKA, James et al. Independent work: choice, necessity, and the gig economy. Mckinsey Institute Featured Insights, out. 2016. Disponível em: https://www.mckinsey. com/featured-insights/employmentand-growth/independent-work-choice-necessity-and-the-gig-economy. Acesso em: 19 mar. 2018. 
MADRID. Juzgado de lo social n 19 de madrid. № de Resolución: 188/2019, 2019a.

MPT MINISTÉRIO PÚBLICO DO TRABALHO. Empresas de transporte, plataformas digitais e relações de emprego: um estudo do trabalho subordinado sob aplicativos. Gráfico Movimento, Brasília: Ministério Público do Trabalho, 2018.

O'CONNOR, Sarah. "Bogus" self-employment deprives workers of their rights. Financial Times, 18 ago. 2015. Disponível em: <www.ft.com/cms/s/0/e6231ad6-45a6-11e5-af2f-4d6e0e5eda22.html\#axzz3k7YZIUhX>. Acesso em: 10/05/2017.

OFFE, Claus. Trabalho \& sociedade: problemas estruturais e perspectivas para o futuro da sociedade do trabalho. Rio de Janeiro: Tempo Brasileiro, 1989.

PARROT, James A.; REICH, Michael. Report for the New York City Taxi and Limousine Commission. New York: CNYCA/CWED, 2018. Disponível em: https:// static1.squarespace.com/static/53ee4f0be4b015b9c3690d84/t/5b3a3aaa0e2e72ca74079142/1530542764109/Parrott-Reich+NYC+App+Drivers+TLC+Jul+2018jul1. pdf. Acesso em: 15 nov. 2019.

PERFIL dos Entregadores Ciclistas de Aplicativo. Aliança Bike, Entregadores Ciclistas de Aplicativos, São Paulo, jul. 2019. Disponível em: http://aliancabike.org.br/pagina.php?id_ secao=10\&id_page $=50$. Acesso em: 10 set. 2019.

POLANYI, Karl. A grande transformação: as origens de nossa época. Rio de Janeiro: Campus, 2000.

POULANTZAS, Nicos. Poder político e classes sociais. São Paulo: Martins Fontes, 1977.

RIESCO-SANZ, Alberto. Empresas evanescentes, falsos autónomos y cooperativas de trabajo asociado en la industria cárnica. In: . (Coord.) Fronteras del trabajo asalariado. Madri: Editorial La Catarata, 2020.

ROSENFIELD, Cinara. Autoempreendedorismo: forma emergente de inserção social pelo trabalho. Revista Brasileira de Ciências Sociais, São Paulo, v 30, n. 89, p. 115-128, 2015. STANDING, Guy. The precariat: the new dangerous class. Londres: Bloomsbury Academic, 2011.

Understanding the precariat through labor and work. International Institute of Social Studies, Haia, v. 45, n. 50, p. 963-998, 2014.

STANDING, Guy. A Revolt Is Coming for Cloud Labor. Huffingtonpost, News, 27 out. 2016. Disponível

em: http://www.huffingtonpost.com/guy-standing/cloud-labor-revolt_b_8392452.html. Acesso em: 05

maio 2017.

A revolt is coming for cloud labor. Huffpost, 27 out. 2016. Disponível em: <www. huffingtonpost.com/guy-standing/cloud-labor-revolt_b_8392452.html>. Acesso em: 8 jun. 2020.

THE HAMILTON PROJECT. A Proposal for Modernizing Labor Laws for Twenty-FirstCentury Work: The "Independent Worker". DISCUSSION PAPER 2015-10 I DEC. 2015. Disponível em: https://www.hamiltonproject.org/assets/files/modernizing_labor_laws_for_ twenty_first_century_work_krueger_harris.pdf. Acesso em: 20 nov. 2018.

UK. Employment status report. Office of Tax Simplification. Londres, . 2015. 